A N N A L E S

UNIVERSITATIS MARIAE CURIE-SKŁODOWSKA

LUBLIN - POLONIA

VOL. XXXIV

SECTIO FF

$1-2016$

\title{
JERZY SKWARZYŃSKI
}

City, University of London

\section{Meet the Mountbattens in communist Britain: reacting to the provocative ideas conveyed in The Queen and I by Sue Townsend}

\footnotetext{
Mountbattenowie z komunistycznej Brytanii:

reakcje na prowokacyjne idee zawarte w powieści Sue Townsend Królowa i ja
}

\section{INTRODUCTION}

According to Leonard Forster's definition, a translation is a text "which fulfils the same purpose in the new language as the original did in the language in which it was written" (as cited in Nida 2012: 146). Matthew Arnold's point corresponds to Forster's observation: "A translation should affect us in the same way as the original may be supposed to have affected its first hearers" (as cited in Nida 2012: 148). In this statement, Arnold focuses on literary texts, where Forster's "purpose" is to evoke a particular reaction, to "affect" the readers in a certain way. Conveying humour in comedy novels, a sense of unease in ghost stories, or the fast-paced narration in a page-turner is, to a great extent, a question of accurate linguistic choices based on a translator's grasp of the language and culture of both the source text (ST) and target text (TT). The differences between the cultures of ST and TT may cause considerable challenges for translation, especially if the ST abounds in references and allusions to the culture it represents.

The Queen and I, a novel written in 1992 by Sue Townsend (1946-2014), is a salient example of such a culture-bound text. It tells a fictitious story of the Republicans gaining power and overthrowing the monarchy. The Queen and her relatives are relocated from Buckingham Palace to a working-class council estate. 
Throughout the novel, the readers follow the royals as they struggle with their new surroundings and neighbours. The striking differences between the (formerly) well-situated and sophisticated royals and poorly educated members of the underclass are the main theme of the story. A parallel plot in the novel follows the Republican Prime Minister, Jack Barker, a fictional character leading the People's Republican Party, which also exists only in the pages of the novel ${ }^{1}$. Barker's communist policies bring the country to the verge of bankruptcy. Finally, Britain loses its independence and becomes a subject of the Empire of Japan. In the final chapter it is revealed that the whole story was just the Queen's nightmare.

Upon writing the book, Townsend must have assumed that certain facts would be obvious to British readers. We can presume that most British readers of the novel would be familiar with most of the royal family members' names, would recognise that Jack Barker and his communist party are fictional, and would know what the NHS and "Meals on Wheels" are. This may not be the case with Polish readers. Nonetheless, these features of the British society can be easily explained (e.g. by means of footnotes). What poses a real challenge is conveying the connotative meaning of some of the notions and situations presented in the book.

Roman Lewicki (2000) thoroughly analyses the notion of denotative and connotative meanings of texts in the context of translation. Denotation is the clear, unobtrusive meaning of symbols, words or notions, whereas connotation focuses on the associations that are derived from it. The translation of connotative meaning is one of the most challenging translation tasks, especially with a text so culturespecific as The Queen and $I$.

According to the definitions cited at the beginning of this section, a good translation affects its readers in the way the original affected the ST recipients. Eugene Nida provided a list of four requirements to achieve this goal: "(1) making sense, (2) conveying the spirit and manner of the original, (3) having a natural and easy form of expression, and (4) producing a similar response" (Nida 2012: 148). Considering these provisions, the translation of such a culture-specific text may demand in-depth research into Polish respondents' knowledge of those elements of the British culture in the 1990s that we can assume innate for ST readers. This difference in cultural awareness between the two groups of readers is likely to exert considerable influence on the translator's decisions. In order to produce a translation as clear to TT readers as the original is to ST readers, these differences must be properly assessed beforehand. I believe that some potential cultural ambiguities and differences may be cleared up by means of paratext, e.g. prefaces and footnotes. Inasmuch as commentary provided by a translator may be, as Philip

${ }^{1}$ In the years 1990-1997, a member of the Conservative Party, John Major, was the UK Prime Minister. 
E. Lewis states, necessary upon translation of texts that are deeply embedded in the ST culture (Lewis 2012), it does not guarantee that the text will evoke the same reaction among TT readers, even though it may clarify many ambiguities.

I attempted to explore this hypothesis by means of conducting an online survey. The source material consisted of The Queen and I and its only existing translation into Polish Królowa i ja by Hanna Pawlikowska-Gannon published in 1994. I wanted to assess how the understanding and response to culture-specific notions were different between the British readers of the original and Poles who read the translation. Both British and Polish groups consisted of 100 respondents. The British version of the survey was active from 26 February 2015 to 10 May 2015; the Polish version was active from 24 February 2015 to 10 May 2015.

Participants were presented with six ideas from the novel and were asked to mark the reaction that reflected their feelings best. They could choose from the following options: amusement, indifference, shock, confusion, disgust, fear and offence $^{2}$. They were also able to leave comments or alternative answers for every statement. The results showed how significant the discrepancies between these two cultures are.

Having marked their reactions to the statements, the participants answered additional questions. Britons were asked about their nationality. Out of $82 \%$ that answered, 37.32\% were English, 1.22\% Irish, 14.63\% Scottish and 26.83\% Welsh. Poles were asked how they would describe their knowledge of British culture. Answers were given by $83 \%$ of respondents and the options were as follows: none $(25.3 \%)$, fragmentary $(46.99 \%)$, extracurricular $(18.07 \%)$ and professional (9.64\%).

In sections 2 to 6 I compare Britons' and Poles' reactions to each statement and underline the most striking differences between them; I also consider comments posted by some of the participants. Percentage results are presented below every chart in the order from the most popular to the least popular option. In the final part of this paper I suggest possible translation solutions and provide directions for future research.

What has to be stressed before the analysis of the results is that they are by no means exhaustive. The modest number of respondents who took part in the study examining only one novel cannot serve as a base for establishing translation norms and generalisations (Toury 1995: 38).

${ }^{2}$ The version for the Polish respondents was written in Polish. 


\section{STATEMENT 1: THE BRITISH ROYAL FAMILY HAS BEEN ABOLISHED AND RELOCATED FROM BUCKINGHAM PALACE TO A WORKING-CLASS COUNCIL ESTATE}

$95 \%$ of the British respondents marked their reaction to this statement.

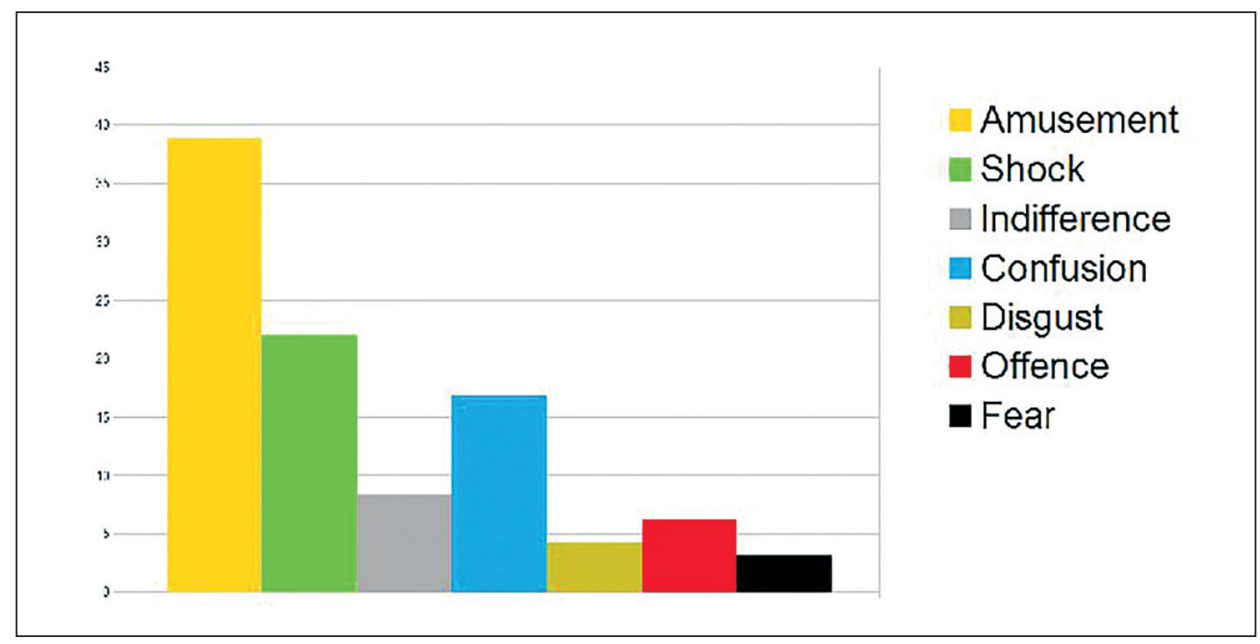

Fig. 1. Statement 1, reactions of the British participants (Amusement $-38.95 \%$, Shock $22.11 \%$, Confusion $-16.84 \%$, Indifference $-8.42 \%$, Offence $-6.32 \%$, Disgust $-4.21 \%$, Fear $3.16 \%)$.

Comments were posted by six British respondents ${ }^{3}$ :

(1) It's fiction right?

(2) Consider the royal family should be in Buckingham palace

(3) Can I go meet them?

(4) Although I don't wholley agree with the idea of a monarchy due to the inequality associated with it, I do like the tradition it brings and the rich history. Plus they generate extra revenue to the country and are highly generous to charities. I do wish that they earned their own money so would be less of a burden on the tax payer ${ }^{4}$.

(5) It is how it should be.

(6) It would be interesting to see them live the same way as everyone else does. It would being amusing to see if they could actually cope.

\footnotetext{
${ }^{3}$ The original spelling is preserved for all comments.

${ }^{4}$ Every tax payer in the UK pays 56 pence a year for the maintenance of the royal family (Milmo 2014).
} 
The idea of abolishing the monarchy in the UK and forcing the royal family to lower their standard of living seemed amusing to the majority of British respondents. That may be surprising to many Polish respondents, as the Queen and monarchy are perceived to be symbols of the United Kingdom. Britons' attitude towards the royal family seems to be more conflicted.

The majority (95\%) of Polish respondents who answered that question also found this statement amusing.

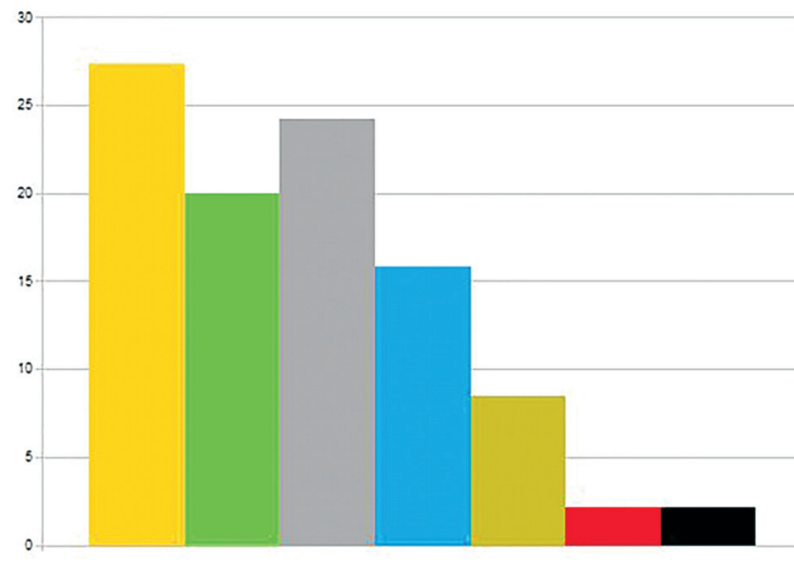

Amusement

- Shock

$\square$ Indifference

Confusion

Disgust

Offence

- Fear

Fig. 2. Statement 1 , reactions of the Polish participants (Amusement $-27.37 \%$, Indifference $-24.21 \%$, Shock $-20 \%$, Confusion $-15.79 \%$, Disgust $-8.42 \%$, Fear $-2.11 \%$, Offence $-2.11 \%$ ).

Polish respondents posted eight comments:

(1) Piesek radzi sobie najlepiej. ::) [The little dog copes the best ::)]

(2) Zainteresowanie [Interest]

(3) Każdy przeciętny człowiek, nawet jeśli się do tego nie przyznaje, nie miałby nic przeciwko temu, żeby wielcy tego świata zasmakowali codzienności maluczkich [Every average human, even if they don't say it out in the open, wouldn't mind if the great of this world had a sense of what the everyday life of the common folk tastes like]

(4) Odraza [Abhorrence]

(5) Bezczelność! [Audacity!]

(6) na pewno się tego nie spodziewali. tak obrotu sprawy, jak i nowych warunków lokalowych. [they didn't expect it for sure, such a turn of events, as well as new accommodation conditions.]

(7) Lekki smutek [Mild sadness]

(8) PRECZ Z KOMUNĄ! [AWAY WITH COMMUNISM!] 
Interestingly, the percentage of Polish respondents who found it amusing (27.37\%) was significantly lower than the percentage of British respondents who marked this reaction $(38.95 \%)$; moreover, almost as many Polish respondents were indifferent to the idea $(24.21 \%)$. Only $8.42 \%$ of the British respondents shared the same opinion. From a translator's point of view this may be the most thought-provoking difference from this statement. Regardless of their opinions and attitude towards the royal family, most Britons expressed a strong reaction to the idea, while many Poles were not moved by it at all. Nevertheless, some individuals among the Polish respondents expressed their intense feelings against the concept of abolishing the monarchy in Britain, as shown in the comment section: their reactions varied from indignation to sadness. This may be interpreted as the affection some Poles feel for the royal family, in contrast to the reactions of British respondents, which deserves a separate investigation.

\section{STATEMENT 2: THE QUEEN MOTHER'S FICTITIOUS DEATH IN 1992 HAS BEEN DESCRIBED AND PUBLISHED AS A SUBPLOT OF A COMEDY NOVEL}

Elizabeth Angela Marguerite Bowes-Lyon, also known as the Queen Mother, was married to King George II and had two daughters: Queen Elizabeth II and Princess Margaret. She died in her sleep in 2002, ten years after the time when the action of The Queen and $I$ is set.

$89 \%$ of the British participants responded to Statement 2.

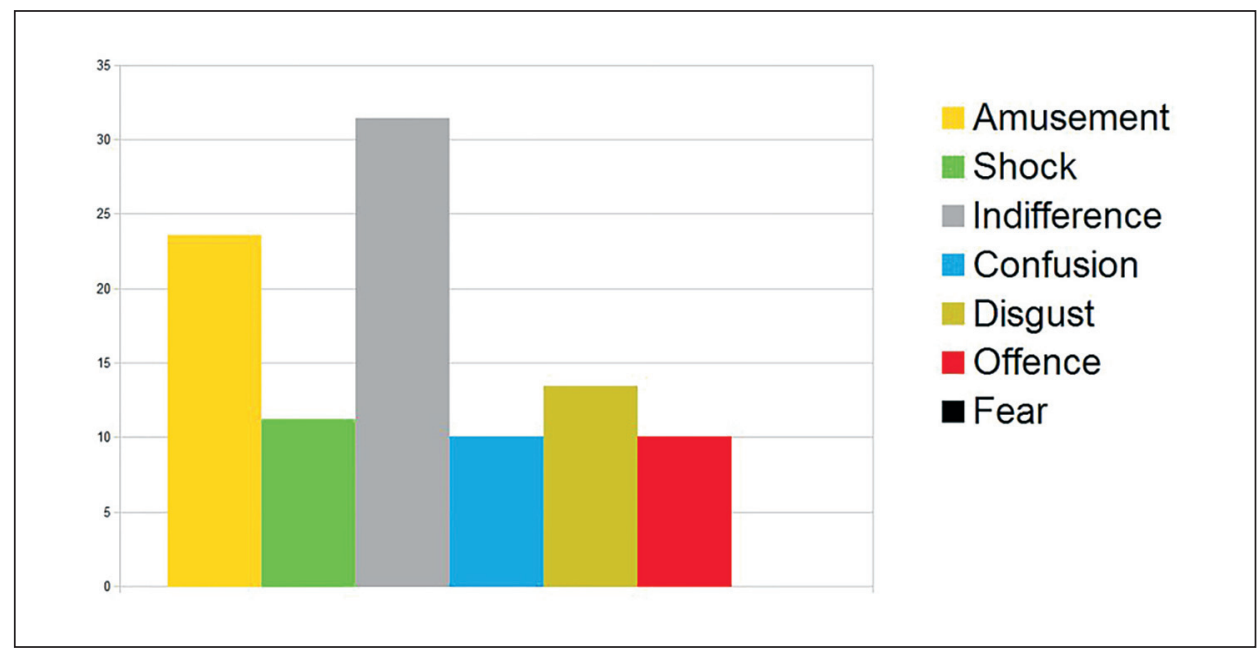

Fig. 3. Statement 2, reactions of the British participants (Indifference $-31.46 \%$, Amusement $-23.6 \%$, Disgust $-13.48 \%$, Shock $-11.24 \%$, Confusion $-10.11 \%$, Offence $-10.11 \%$, Fear $-0 \%$ ). 
Three British respondents commented on this idea:

(1) Why?

(2) That's inappropriate, the topic is quite sensitive

(3) No one would want their loved one to be taken as a comedy plot.

Even though the comments were written by those who seemingly found the idea inappropriate, the majority of British respondents were indifferent to it $(31.46 \%)$. The second biggest group (23.60\%) consisted of participants who were amused by it, which may be linked to the famous British dark humour. Based on reactions to Statement 1, this high percentage of British respondents indifferent to the "death" of the Queen Mother may be interpreted as a provocation: they show that they do not care about the members of the Royal Family any more than they would about any other family they are not related to, ignoring the high social status of the Windsor family and their symbolic meaning and position in British society.

Of the $90 \%$ of Polish respondents who marked their reactions to Statement 2, many were also indifferent, while only $11.11 \%$ found it amusing.

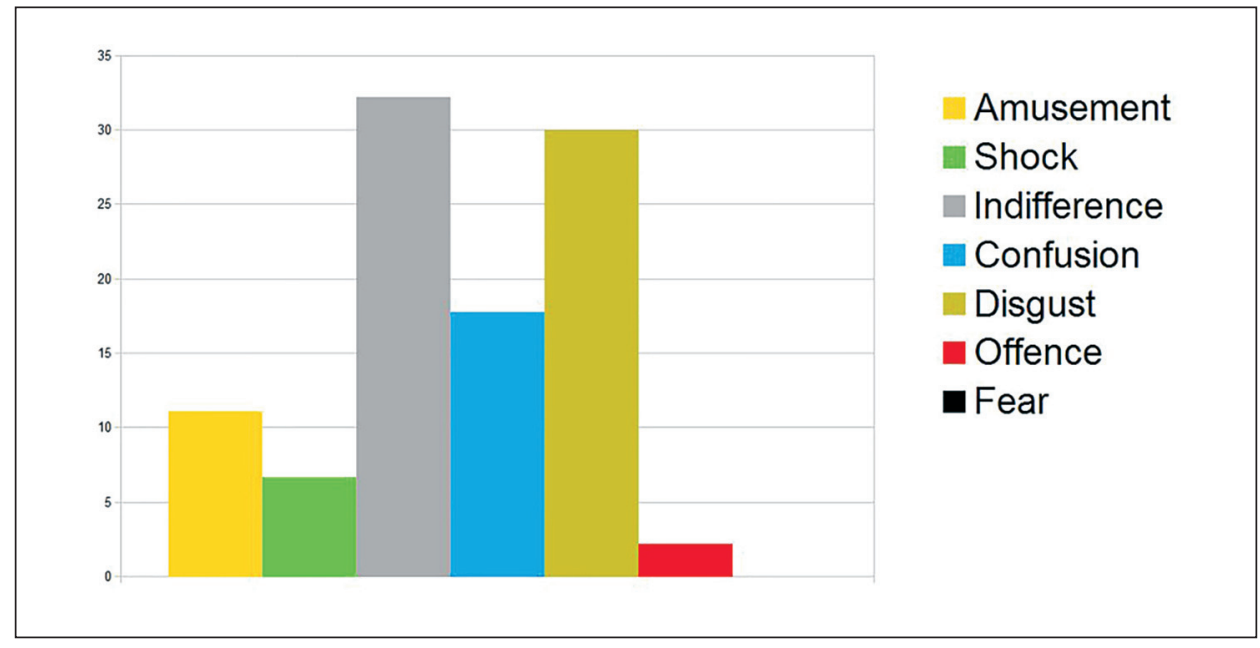

Fig. 4. Statement 2, reactions of the Polish participants (Indifference $-32.22 \%$, Disgust $-30 \%$, Confusion $-17.78 \%$, Amusement $-11.11 \%$, Shock $-6.67 \%$, Offence $-2.22 \%$, Fear $-0 \%$ ).

What strikes one the most is the fact that $30 \%$ of the Polish respondents thought that this idea was disgusting (only $13.48 \%$ of Britons marked this reaction). Four comments were posted:

(1) Wątki komediowe przeplatają się niekiedy z tragicznymi, ale powinno to mieć jakiś cel [Humorous subplots are sometimes interwoven with tragic ones, but it ought to have some purpose] 
(2) Odraza [Abhorrence]

(3) czy to śmierć jest komediowa, czy to że była fikcyjna? [was the death comical or the fact that it was fictitious?]

(4) Jam można z Jej śmierci zrobić wątek poboczny? [Hoa can one describe Her death as a subplot!]

Even though death as such is not a taboo subject in Polish culture, it is not something one should laugh about, especially not upon describing a death of a person still living in real life. Although this subplot is not crucial to the story, it is significant as a means of creating the fictitious world of the novel, thus it cannot be disregarded. Nonetheless, according to the survey results, a Polish readership is not likely to react to this subplot in keeping with Townsend's intentions.

\section{STATEMENT 3: THE QUEEN CHANGES HER SURNAME TO MOUNTBATTEN, SO DO HER CHILDREN. HER GRANDCHILDREN CARRY THEIR FATHERS' SURNAMES}

Mountbatten is a family name of the Queen's husband, Prince Philip. In the novel, he is devastated by the situation he finds himself in and dwells in a neardepressive state. He demands that he is the head of the house (in fact, he barely leaves his bed, let alone support his family) and that the Queen should carry his last name.

$86 \%$ of the British respondents marked their reactions to Statement 3.

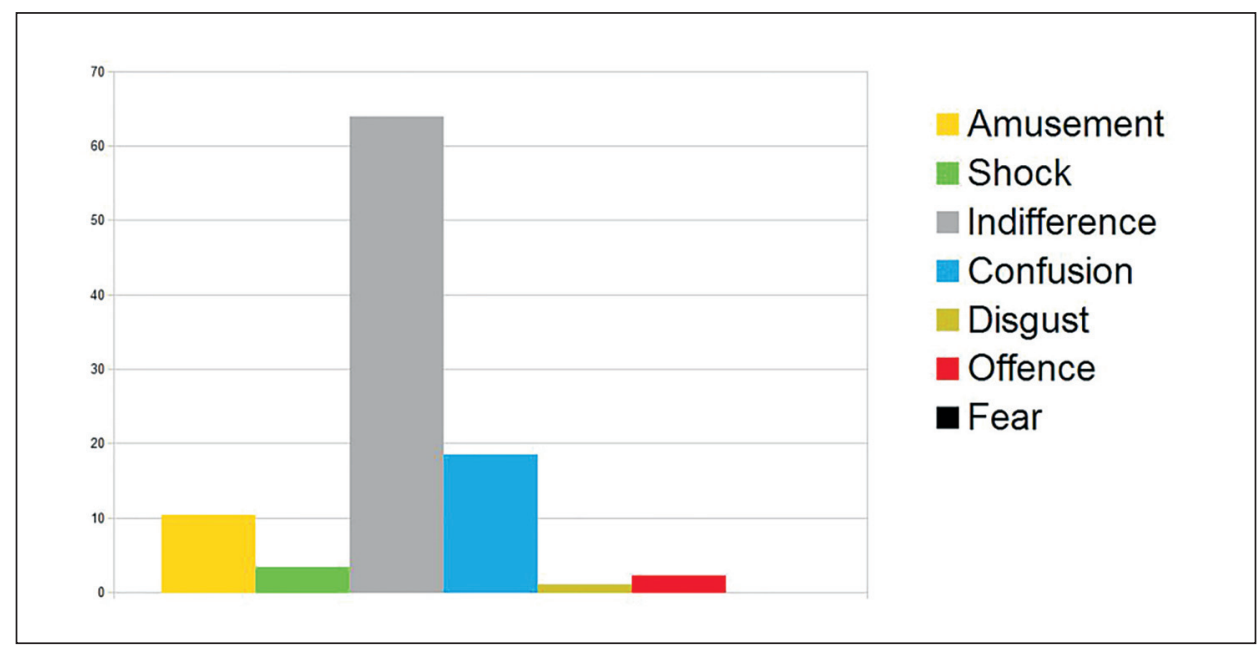

Fig. 5. Statement 3, reactions of the British participants (Indifference $-63.95 \%$, Confusion $-18.6 \%$, Amusement $-10.47 \%$, Shock $-3.49 \%$, Offence $-2.33 \%$, Disgust $-1.16 \%$, Fear $-0 \%$ ). 
Inasmuch as over half the participants were indifferent to this idea, five of them posted interesting comments:

(1) It is a curse of the modern age; that commoners feel they have the right to question the inner workings of the Royal Family. Propriety is dead. 64 million kings and queens, no subjects whatsoever.

(2) Surnames are not really important, it's family that counts

(3) What does the Mountbatten mean?

(4) My actual feeling would be sadness because it's the end of an era and it doesn't seem right.

(5) Why should the male name be carried through the generations?

Comment (3) represents what may be the cause of British indifference exceeding other reactions to the idea: some of them do not know that this is the last name of the Queen's spouse. Comment (1) may relate to the premise of the book; its author is visibly a monarchist. Comment (4) expresses a negative reaction as well; it relates to the symbolic value of the royal family to British society. Comments (2) and (5) refer to social and gender issues rather than to politics; they approach the problem from a more general perspective, ignoring references to royalty. These responses show that questions regarding matters that carry purely symbolic meaning, such as surnames, may lead to discussions touching upon many perspectives of these issues.

The majority of $87 \%$ of the Polish respondents were indifferent to this idea as well.

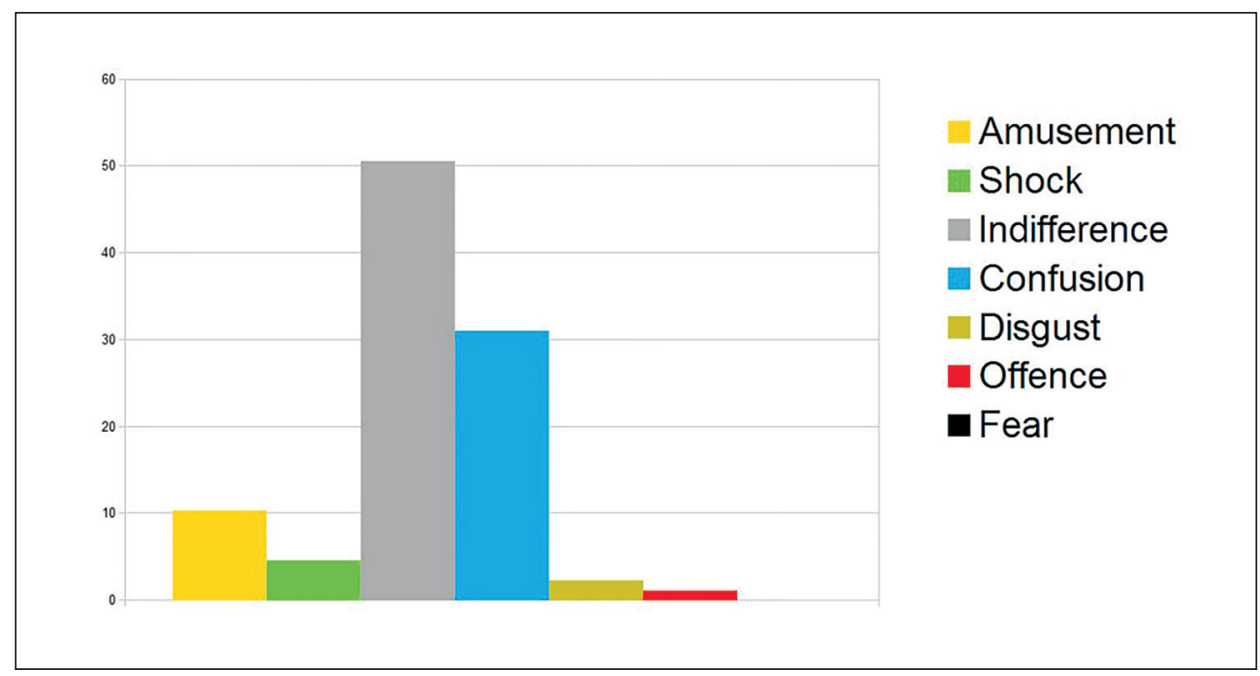

Fig. 6. Statement 3, reactions of the Polish participants (Indifference $-50.57 \%$, Confusion $-31.03 \%$, Amusement $-10.34 \%$, Shock $-4.6 \%$, Disgust $-2.3 \%$, Offence $-1.15 \%$, Fear $-0 \%$ ). 
There were five comments from the Polish respondents:

(1) Intrygujące [Intriguing]

(2) Rozsądne dostosowanie się do nowej sytuacji w imię przeżycia. [Reasonable adjustment to new circumstances in order to survive.]

(3) zmiana nazwiska jest moim zdaniem uzasadniona w przypadku tylko jeśli przodkowie o tym nazwisku dopuścili się jakichś niegodnych czynów i nie chce się być z nimi kojarzonym, nie wiem, czy tak było w tym przypadku. [the change of the last name is justified in such a case only if the ancestors carrying that last name committed some despicable acts and somebody doesn't want to be associated with them, I don't know if this is the case.]

(4) brakuje mi opcji: zrozumienie [I miss the "understanding" option]

(5) Po co zmieniać nazwisko? Poza tym, Saxe-Coburg-Gotha brzmi lepiej. [Why to change the last name? Besides, Saxe-Coburg-Gotha sounds better.]

These comments express a less vigorous approach to the idea. They show a pragmatic stance on the matter or demonstrate the knowledge of the commentators on British culture. In general, the Polish participants did not seem to be as concerned about this concept as a few of their British counterparts who posted thought-provoking comments.

\section{STATEMENT 4: THE UNITED KINGDOM OF GREAT BRITAIN AND NORTHERN IRELAND TRANSFORMS INTO COMMUNIST PEOPLE'S GREAT BRITAIN}

$86 \%$ of the British participants responded to this statement.

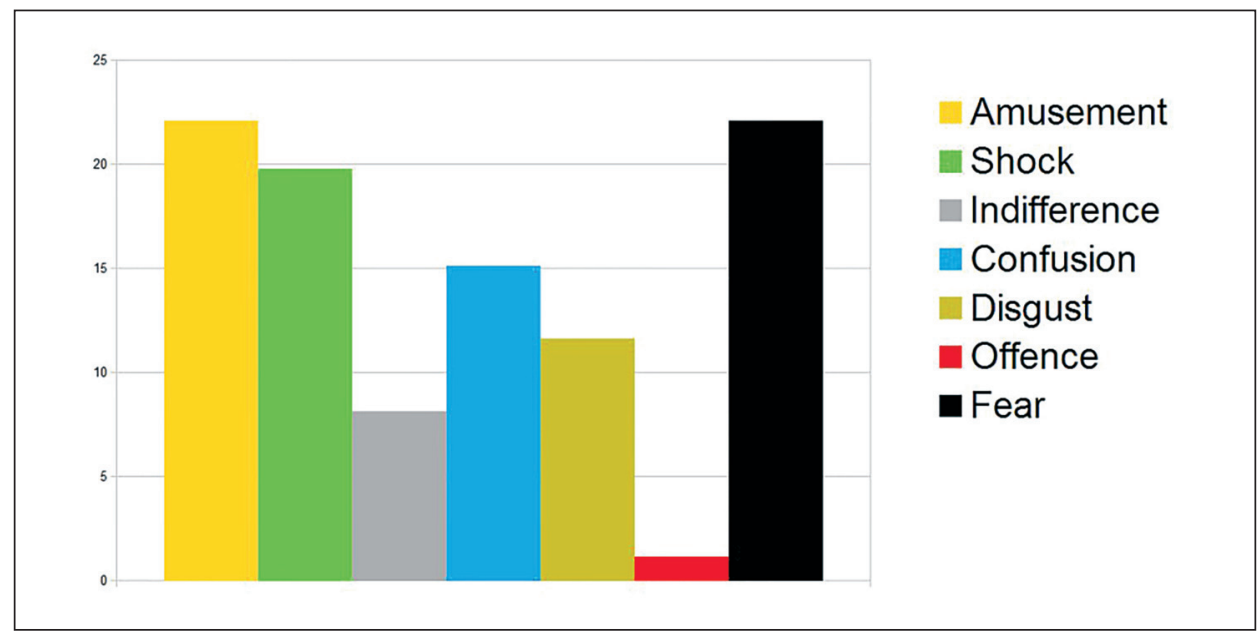

Fig. 7. Statement 4, reactions of the British participants (Amusement $-22.09 \%$, Fear $-22.09 \%$, Shock $-19.77 \%$, Confusion $-15.12 \%$, Disgust $-11.63 \%$, Indifference $-8.14 \%$, Offence $-1.16 \%$ ). 
Seven comments were posted:

(1) I want to read the book now.

(2) Would not work as a society

(3) I don't think people in this country realise how much freedom they actually have.

(4) Rule Britannia. Britain never, ever, ever shall be communist.

(5) Communism is one of the worst things to have ever plagued our earth

(6) Sound's like the sort of book I would want to read.

(7) Concern.

Amusement and fear were chosen by the same percentage of respondents $(22.09 \%)$. Two respondents expressed their interest in reading the book in comments (1) and (6); they both found the idea amusing. Nevertheless, the remaining five comments show a negative attitude towards communism. The authors of comments (2) and (3) were scared by the idea of the UK becoming a communist country, while those who posted comments (4) and (5) felt disgust. These results show the negative attitude of the British respondents towards the idea of their country becoming communist.

The reactions of $87 \%$ of the Polish participants who expressed their attitude to the statement were not as diverse.

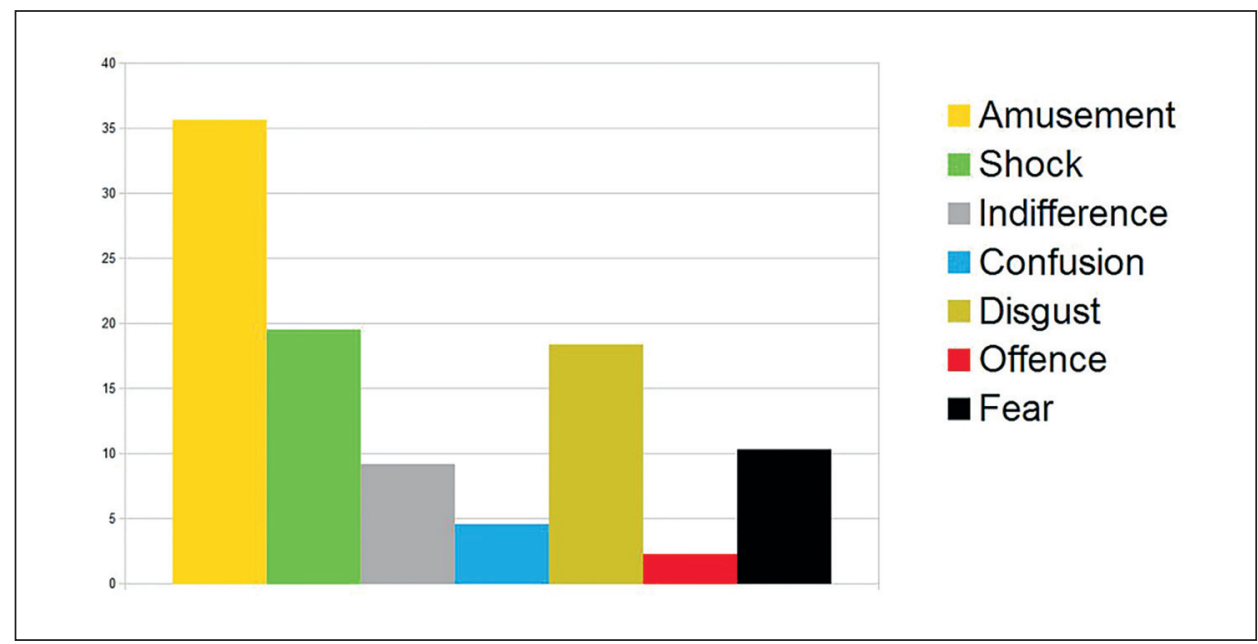

Fig. 8. Statement 4, reactions of the Polish participants (Amusement $-35.63 \%$, Shock $19.54 \%$, Disgust $-18.39 \%$, Fear $-10.34 \%$, Indifference $-9.2 \%$, Confusion $-4.6 \%$, Offence $2.3 \%)$. 
They posted four comments:

(1) Cóż za krok wstecz i do tego groźny [What a step back, plus it's a threatening one]

(2) komunizm raczej nigdy nie będzie lepszą opcją. [communism will never be a better option.]

(3) Wszędzie, gdzie pojawia się określenie "ludowy", musi być śmiesznie. Monty Python w rzeczywistości. [It's always funny when the word "People's" appears. Monty Python in real life.]

(4) Precz z komuną, jak już mówiłem. [Away with communism, as I have said before].

The majority of Polish respondents thought that the statement was amusing. Interestingly, Britons, who have never experienced living under communist rule, seem to be more disturbed by the idea of Britain becoming a communist country. I believe that the emotional factor has to be taken into account: when answering this question Britons were thinking about their homeland. Polish respondents thought about what is one of the most powerful countries in Europe, to which many of them emigrate. If a parallel statement had been provided ("The Republic of Poland transforms into the communist Polish People's Republic") the reactions of Britons may have been different, as well as those of the Poles. Not only would they think about their own country, but they would probably consider the fact that Poland was communist for almost five decades. Poland's communist past and its continuing influence on the present still cause heated debates in Poland. The idea of Poland becoming communist again, even hypothetically, could trigger a fierce discussion showing Polish people's complicated and extremely emotional attitude towards their past, fuelled by radically different interpretations of key events in Polish history. Communism is perceived in a completely different way by Britons and Poles due to the different historical and social associations. If we combine these differences with discrepancies between Britons' and Poles' approaches to the United Kingdom, it will become quite clear that their reactions to this statement had to be fundamentally different. 


\section{STATEMENT 5: THE UK HAS BEEN TAKEN UNDER THE CONTROL OF AN EAST ASIAN COUNTRY, THE CITIZENS OF WHICH OFTEN MIGRATE TO GREAT BRITAIN}

$82 \%$ of the British respondents marked their reactions to this statement.

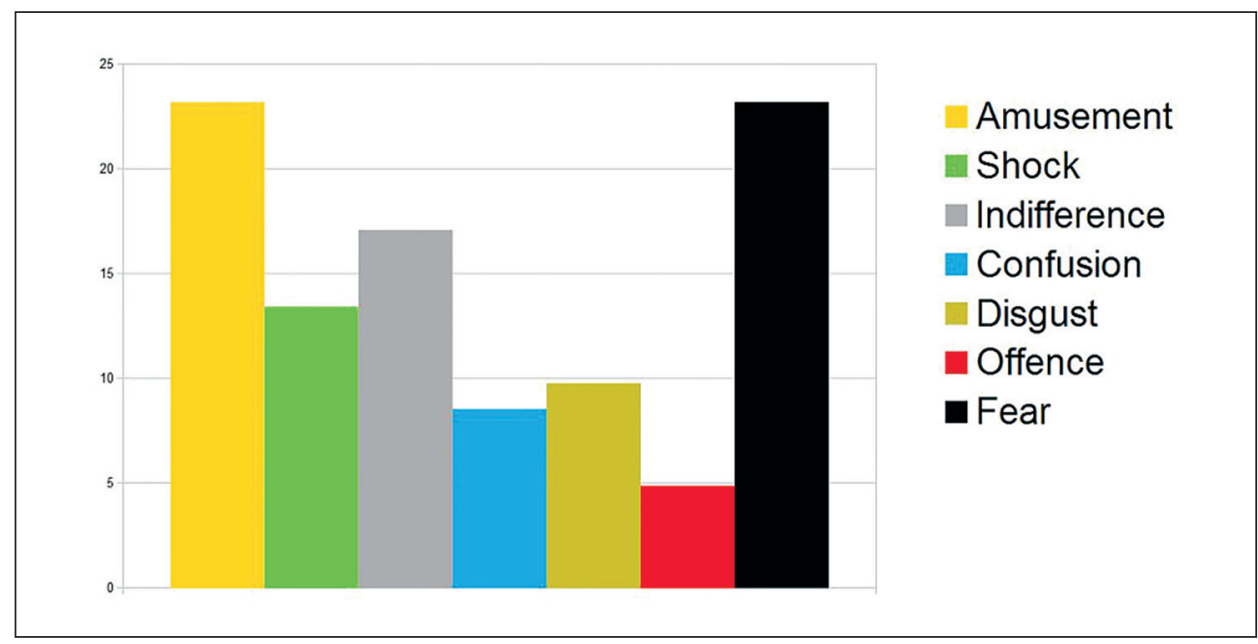

Fig. 9. Statement 5, reactions of the British participants (Amusement $-23.17 \%$, Fear $-23.17 \%$, Indifference $-17.07 \%$, Shock $-13.41 \%$, Disgust $-9.76 \%$, Confusion $-8.54 \%$, Offence $-4.88 \%$ ).

Five comments were posted:

(1) If you were to turn Britain over, it would say 'made in China' on the underside.

(2) The UK could lose its individuality and have lots of rules imposed on it.

(3) More interested than full on amusement.

(4) as long as it's a two way street, I don't care!

(5) if they migrate here then they should not disrespect us and take over our country

As with the previous statement, the two dominant reactions among the British respondents were fear (23.17\%) and amusement (23.17\%). Nevertheless, the percentage of respondents indifferent to this idea was considerably higher than in the case of the previous statement (17.07\% and $8.14 \%$ respectively).

The reactions marked by $84 \%$ of the Polish participants were quite similar to those given by the British respondents. 


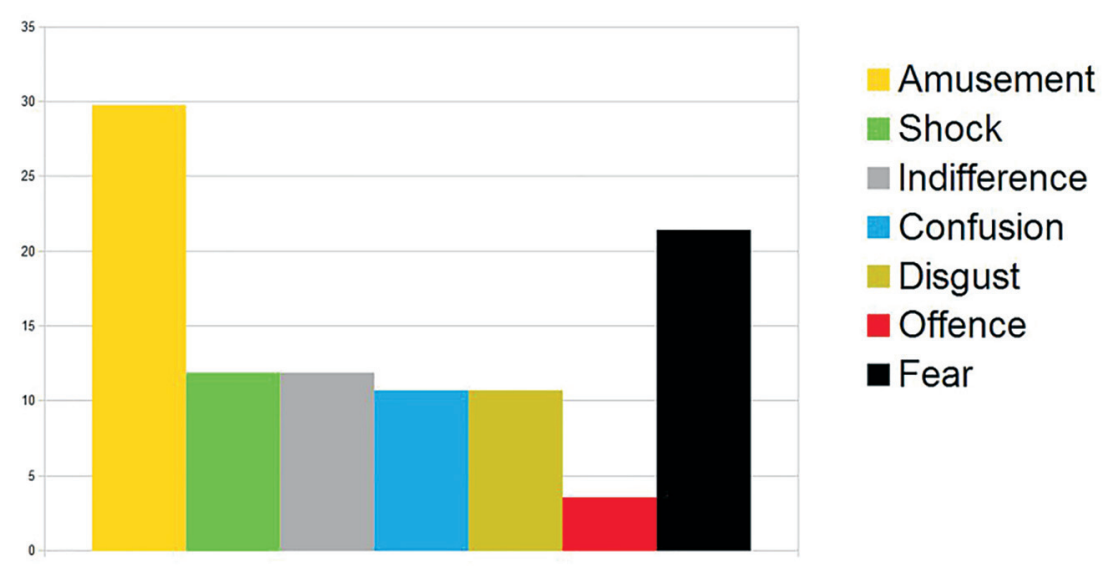

Fig. 10. Statement 5, reactions of the Polish participants (Amusement $-29.76 \%$, Fear $21.43 \%$, Indifference $-11.9 \%$, Shock $-11.9 \%$, Confusion $-10.71 \%$, Disgust $-10.71 \%$, Offence $-3.57 \%$ ).

They posted six comments:

(1) Ach ta imperialistyczna karma. [Ach, the imperialistic karma.]

(2) brzmi dziwnie znajomo [sounds peculiarly familiar]

(3) To nie może się dobrze skończyć [It can’t end well]

(4) oto czym zagraża nadmiar ludności napływowej [these are the threats of extensive immigration]

(5) To się dzieje naprawdę! Tu i teraz. Tzn., tam i teraz. Allah akbar i do przodu! [This is happening in real life! Here and now. I mean, there and now. Allah akbar and move forward 5 !]

(6) To było do przewidzenia. Do tego prowadzi marksizm... [It could have been predicted. This is what Marxism leads to...]

Comments (2), (4) and (5) quite blatantly refer to the contemporary situation regarding immigration in the United Kingdom and Europe in general. In the time span when the surveys were active, the European migrant crisis became a widely-debated subject worldwide. On 12 April 2015, 400 migrants drowned in the Mediterranean Sea; seven days later another 900 people suffered the same fate while trying to reach Italy (Bremmer 2015), which increased the number of migrant deaths to 1600 . This situation might have been one of the reasons for

5 „I do przodu” is the reference to Tadeusz Rydzyk's famous saying „Alleluja i do przodu” [Hallelujah and move forward]. Rydzyk is a politically and socially influential, radically right-wing catholic priest, the director of a religious radio station (Radio Maryja) and a television channel (TV Trwam). 
xenophobic tendencies increasing in Europe. Comments posted by the Polish participants show their negative attitude towards migrants. British respondents did not share these concerns, although a far greater number of migrants head to the United Kingdom than Poland.

\section{CONCLUSION}

Results presented above confirm Lewis's idea that translations of culturallyembedded texts may require commentary in order to be understandable to TT readers. Unfortunately, this will not guarantee that TT readers will react in the way ST readers do. A translator's commentary in the form of a preface, occasional footnotes or an afterword may only fill in the gaps in the reader's understanding of the story; the meaning and humorous aspect of features such as the Mountbatten reference may be clear and enjoyable, but reactions based on emotions cannot be evoked unless a TT reader has developed an emotional relationship with what can be called Britishness. Even if they did, it would be different from the relationship of a Briton to Britishness, which was showed in some of the comments of Polish participants, especially those regarding the symbolic meaning of the monarchy.

Nevertheless, extensive commentary explaining the cultural references and historical background of British society in the 1990s seems inevitable. Filling potential blank spaces in the knowledge of the reader is all that a translator could do to make sure that the reader is provided with the stimuli equal to those presented in the original. The interpretation of a text, supplemented by the translator's comments, is left to the reader.

The use of paratextual additions is an element of postcolonial translation approaches, such as Appiah's thick translation, which includes "thick description of the context of literary production" (2012: 341) or Nabokov's urge to accompany translations with "copious footnotes, footnotes reaching up like skyscrapers to the top of this or that page so as to leave only the gleam of one textual line between commentary and eternity" (2012: 125). Even though their postcolonial theories advocate footnotes, their goal - to fill translations with paratext to educate the reader and bring as much of the ST culture to the TT readership as possible - does not comply with my argument, which is to apply paratext in translation only when it facilitates the reception of a given TT.

The results of my limited survey indicate many aspects of the reception of The Queen and I which could be investigated further. A more detailed research into the understanding Poles have of British culture could help estimate how much should be explained in the translator's commentary. A closer look at the attitudes towards communism might be beneficial in creating a Polish version of the text; more incisive research regarding Poles' attitudes to their communist past contrasted with the idea of the UK becoming communist might also add to the translator's 
decision-making process. The ways in which Poles perceive the elements of the British civilisation (and vice-versa) also deserve a much closer investigation, as the results of my small study may only be treated as indicative for the directions of future research.

\section{BIBLIOGRAFIA}

Appiah K. A., 2012, Thick Translation, [in:] The Translation Studies Reader. Third Edition, L. Venuti (ed.), Abingdon, s. 331-343.

Brenner I., 2015, These 5 Facts Explain Europe's Deadly Migrants Crisis, “Time”, April 23, [in:] http://time.com/3833333/ian-bremmer-europe-migrants-deaths/ [dostęp: 10.02.2016].

Lewicki R., 2000, Obcość w odbiorze przektadu, Lublin.

Lewis P. E., 2012, The measure of translation effects, [in:] The Translation Studies Reader. Third Edition, L. Venuti (ed.), London, s. 220-239.

Milmo C., 2014, Royal family expenses: Taxpayers pay 56p each for upkeep of monarchy - and royals insist it's 'value for money', “The Independent", June 25, [in:] http://www.independent. co.uk/news/uk/politics/cost-of-royal-family-rises-twice-as-fast-as-inflation-9563293.html [dostęp: 10.02.2016].

Nabokov V., 2012, Problems of Translation: “Onegin” in English, [in:] The Translation Studies Reader. Third Edition, L. Venuti (ed.), London, s. 113-125.

Nida E., 2012, Principles of correspondence, [in:] The Translation Studies Reader. Third Edition, L. Venuti (ed.), London, s. 141-155.

Toury G.,1995, Descriptive Translation Studies and Beyond, Amsterdam.

\section{STRESZCZENIE}

Artykuł stanowi analizę badania, które przeprowadziłem w celu zdobycia materiału potrzebnego do przygotowania mojej pracy licencjackiej. Istotą badania było porównanie reakcji Brytyjczyków i Polaków na kontrowersyjne wątki zawarte w powieści Sue Townsend Królowa i ja z 1992 roku. W tekście zawarto komentarze uczestników i odniesiono się do nich podczas analizy. Wyniki pokazują, że paratekst dodany przez tłumacza bywa niezbędny, chociaż może on jedynie wypełnić luki w wiedzy czytelnika - nie sprawi, że emocjonalne reakcje czytelnika thumaczenia będą takie, jak reakcje czytelnika oryginału.

Slowa klucze: przekład literacki, paratekst, przypisy, odniesienia kulturowe

\section{SUMMARY}

This article is an analysis of the survey which I conducted to obtain data necessary for my BA thesis. Its goal was to compare the reactions of the Britons and Poles to the provocative ideas presented in 1992 novel by Sue Townsend The Queen and I. The article includes comments provided by the participants, which were taken into consideration in the analysis. The results show that although the translator's paratext is sometimes inevitable, although it may only fill the gaps in the readers' knowledge - it will not provoke the same emotional reaction as the original.

Keywords: literary translation, paratext, footnotes, cultural references 